\title{
Effects of URB937 on an animal model of migraine pain
}

\author{
R Greco ${ }^{1}$, AS Mangione ${ }^{1}$, R De Icco ${ }^{1}$, T Bandiera ${ }^{2}$, G Sandrini ${ }^{3}$, G Nappi ${ }^{3}$, D Piomelli ${ }^{4}$, C Tassorelli $i^{3 *}$ \\ From The European Headache and Migraine Trust International Congress \\ London, UK. 20-23 September 2012
}

Several studies have suggested the existence of interactions between the endocannabinoids and migraine. URB937, a FAAH inhibitor specific to peripheral tissues, causes analgesia in animal models of pain [1]. In this study, we evaluated whether the URB937 administration may alter nociceptive responses in an animal model of migraine based on nitroglycerin (NTG)-induced hyperalgesia [2]. Rats received systemic NTG and URB937 before being evaluated at the Tail flick test or at the Formalin test. The findings show that URB937 did inhibit NTG-induced hyperalgesia at the Formalin test with only a minimal influence on the hyperalgesia at the Tail flick. The data suggest that availability of anandamide probably at the meningeal level is effective in the migraine pain.

\footnotetext{
Author details

'Headache Science Centre, IRCCS National Neurological Institute "C. Mondino" Foundation, Pavia, Italy. ${ }^{2}$ Medicinal Chemistry Drug Discovery and Development, Italian Institute of Technology, Genova, Italy. ${ }^{3}$ Headache Science Centre, IRCCS National Neurological Institute "C. Mondino" Foundation, UCADH Pavia, Italy. ${ }^{4}$ Departments of Pharmacology and Biological Chemistry, University of California, Irvine, CA, USA.
}

Published: 21 February 2013

\section{References}

1. Clapper JR, Moreno-Sanz G, Russo R, Guijarro A, Vacondio F, Duranti A, Tontini A, Sanchini S, Sciolino NR, Spradley JM, Hohmann AG, Calignano A, Mor M, Tarzia G, Piomelli D: Anandamide suppresses pain initiation through a peripheral endocannabinoid mechanism. Nat Neurosci 2010, 13(10):1265-70.

2. Tassorelli C, Greco R, Wang D, Sandrini M, Sandrini G, Nappi G: Nitroglycerin induces hyperalgesia in rats-a time-course study. Eur J Pharmacol 2003, 464(2-3):159-62.

\section{doi:10.1186/1129-2377-14-S1-P68}

Cite this article as: Greco et al:: Effects of URB937 on an animal model of migraine pain. The Journal of Headache and Pain 2013 14(Suppl 1):P68.

${ }^{3}$ Headache Science Centre, IRCCS National Neurological Institute

"C. Mondino" Foundation, UCADH Pavia, Italy

Full list of author information is available at the end of the article

Submit your manuscript to a SpringerOpen ${ }^{\circ}$ journal and benefit from:

- Convenient online submission

- Rigorous peer review

- Immediate publication on acceptance

- Open access: articles freely available online

- High visibility within the field

- Retaining the copyright to your article

Submit your next manuscript at $\boldsymbol{\sim}$ springeropen.com
(C) 2013 Greco et al; licensee Springer. This is an Open Access article distributed under the terms of the Creative Commons Attribution License (http://creativecommons.org/licenses/by/2.0), which permits unrestricted use, distribution, and reproduction in any medium, provided the original work is properly cited. 